\title{
The Influence of Nitrogen Fertilization on Waterlogging Stresses in Fagus sylvatica L. and Quercus robur L.
}

\author{
Glynn C. Percival and Ian P. Keary
}

\begin{abstract}
The aims of this study were to determine the influence of nitrogen $(\mathrm{N})$ fertilizers on tree tolerance under prolonged waterlogging conditions and investigate the effect of $\mathrm{N}$ fertilization on aiding tree recovery from waterlogging damage using containerized English oak (waterlogging-intermediate) and European beech (waterlogging-sensitive) as test species. English oak proved to be more waterlogging-tolerant than European beech. Tree vitality as measured by chlorophyll fluorescence, photosynthetic rates, leaf chlorophyll content, stomatal conductance, leaf and root protein concentration, and foliar $\mathrm{N}$ content was consistently higher in trees in which $\mathrm{N}$ fertilizers were added to the waterlogged solutions compared with trees waterlogged with tapwater only for 18 days. Measurement of light absorbance, light trapping, electron transport, and dissipation fluxes per leaf cross-section of photosystem II after the 18-day waterlogging period indicated a beneficial influence of $\mathrm{N}$ fertilization on leaf photosynthetic processes at the cessation of the waterlogging period. Addition of $\mathrm{N}$ induced greater resource allocation in favor of roots over shoots in both tree species. At the cessation of the 18-day waterlogging period and after a 10-day regeneration period, growth (leaf area, shoot, root, total plant dry weight) was constantly higher in $\mathrm{N}$ waterlogged trees compared with non- $\mathrm{N}$ waterlogged ones. In a separate study, recovery rates of trees as measured by chlorophyll fluorescence, photosynthetic rates, leaf chlorophyll content, and stomatal conductance over a 6-week period after the cessation of 18 days waterlogging were $30 \%$ to $50 \%$ higher in N-fertilized trees compared with non-N-fertilized trees irrespective of species. In all cases, nonfertilized trees had the least capacity for recovery. In addition, leaf area, shoot, root, and total plant dry weight were higher in $\mathrm{N}$-fertilized trees compared with nonfertilized ones. Results of this investigation indicate 1) applications of $\mathrm{N}$ fertilizers enhance the tolerance of trees under prolonged waterlogged conditions; and 2) applications of $\mathrm{N}$ fertilizers after waterlogging stress would be of benefit to improve tree recovery rates and growth. From a practical point of view, $\mathrm{N}$ fertilization $14.5 \mathrm{~g}(0.51 \mathrm{oz})$ or greater $\mathrm{N}$ per liter $(0.26$ gal $)$ of water is tentatively suggested based on preliminary results of this study.

Key Words. Chlorophylls; chlorophyll fluorescence; English oak; European beech; photosynthesis; physiogenic stress; plant health care; protein; root deoxygenation; stress enzymes, stress tolerance.
\end{abstract}

Soil deoxygenation as a result of excess water application, impeded drainage, mechanical compaction, or impermeable surface coverings is an almost ubiquitous factor in the urban landscape (Percival and Hitchmough 1995). In waterlogged soils, air spaces become filled with water delaying the diffusion of gases among the atmosphere, rhizophere, and roots (Hitchmough 1994). Dissolved oxygen is further depleted from the soil solution by respiration of roots and soil microorganisms. Depletion of dissolved oxygen in waterlogged soils can occur in several hours leading to hypoxia (deficiency in oxygen reaching the tissues) or anoxia depending on soil temperature, respiration activity of the plant, and the frequency and duration of soil saturation. Once oxygen concentrations fall below $15 \%$ within soil pores, root functioning is impaired affecting numerous physiological and metabolic processes (Kozlowski et al. 1991; Crook 1992). These include disintegration of leaf ultra structure leading to wilting, chlorosis, abscission, and reduced photosynthetic capacity as well as stem hypertrophy, blackening of roots, and death (Percival 2004). Cytological investigations conducted in woody plant roots indicated water stress damages the cellular membranes of root tips. At different development stages, the occurrence of damage such as lack of protoplasm, formation of membrane vesicles, and coagulation of cytoplasmic content has been demonstrated (Chiatante et al. 2000). At the whole plant level, symptoms include yellowing leaves, particularly between the veins, soft tissue at the leaf base, wilting, shoot dieback, physical deterioration of the root system that visibly appears blue-black in color, and peeling bark (Mclean 1993).

Applications of nitrogen $(\mathrm{N})$ fertilizers have been shown to modify plant responses to waterlogging in a range of economically important agricultural crops. Pezeshki et al. (2000) concluded that the growth of planting stocks for wetland mitigation could be improved by $\mathrm{N}$ fertilization in the nursery. Work by Huang et al. (1994a) showed increasing plant nutrient supply improved shoot nitrogen status of wheat genotypes that contributed to superior growth of waterlogged plants compared with nonfertilized controls. Application of calcium nitrate to the surface of waterlogged soils prevented the onset of waterlogging damage as manifest by leaf chlorosis, reduced leaf chlorophyll concentration, and dry weight in barley cultivars (Drew et al. 1979), whereas Hodgson and MacLeod (1987) concluded foliarapplied $\mathrm{N}$ could be used to reduce the effect of prolonged waterlogging in cotton. Although most studies conclude that $\mathrm{N}$ fertilizer application can alleviate some of the adverse effects of prolonged waterlogging in terms of tolerance and survival, this research has been conducted primarily with crop rather than woody ornamentals.

The tactical use of $\mathrm{N}$ fertilizers as an ameliorant against waterlogging damage and recovery from waterlogging stresses in woody plants has received little investigation. The aims of this investigation were to: 
Experiment 1. Determine the effect of $\mathrm{N}$ fertilizers on tree tolerance under prolonged waterlogging conditions; and

Experiment 2. Determine the effect of $\mathrm{N}$ fertilizers in its ability to aid tree recovery from waterlogging damage.

\section{MATERIALS AND METHODS}

\section{Plant Material}

The experiment used 5-year-old containerized stock of European beech (Fagus sylvatica L.) and English oak (Quercus robur L.), waterlogging-sensitive and -intermediate, respectively (Kreuzwieser et al. 2002). Trees were supplied bare root in November 2003 and potted into $10 \mathrm{~L}$ (2.6 gal) pots remaining outdoors subject to natural environmental conditions during the 2004 growing season and watered as required. All pots were supplemented with a granular N:P:K (29:7:9) fertilizer (BOOST, The Doggett Corporation, Lebanon, NJ, U.S.) applied at a concentration of $2.8 \mathrm{~g}(0.1 \mathrm{oz})$ per kilogram $(2.2 \mathrm{lb})$ of growth media (loamy texture with $23 \%$ clay, $46 \%$ silt, $31 \%$ sand, $3.1 \%$ organic carbon, $\mathrm{pH}$ 6.6) to provide soil nutrients over the 2004 growing season. To ensure uniformity of stock for experimental purposes, trees were graded in March 2005 and only those conforming to the listed physical dimensions used:

European beech (Fagus sylvatica L.) - height $1.2 \mathrm{~m}(3.96 \mathrm{ft}) \pm 0.060 \mathrm{~m}$ $(0.20 \mathrm{ft})$, girth $2.8 \mathrm{~cm}(1.12 \mathrm{in}) \pm 0.14 \mathrm{~cm}(0.06 \mathrm{in})$.

English oak (Quercus robur L.), height $1.5 \mathrm{~m}(4.95 \mathrm{ft}) \pm 0.075 \mathrm{~m}(0.25$ $\mathrm{ft})$, girth $3.1 \mathrm{~cm}(1.24 \mathrm{in}) \pm 0.18 \mathrm{~cm}(0.07 \mathrm{in})$.

Both experiments began 4 May 2005 when all trees were in full leaf. All experiments were conducted outdoors subject to natural environmental conditions. During the experimental period, the mean minimum and maximum air temperatures were $7.5^{\circ} \mathrm{C}\left(45.5^{\circ} \mathrm{F}\right)$ and $22.7^{\circ} \mathrm{C}\left(72.9^{\circ} \mathrm{F}\right)$, respectively; daily relative humidity, sunshine hours, and rainfall were $69.8 \%, 7.01 \mathrm{hr}$, and $1.40 \mathrm{~cm}$ (0.6 in), respectively. All studies were conducted at Reading University, Shinfield experimental research site $\left(51^{\circ} 43^{\prime} \mathrm{N},-1^{\circ} 08^{\prime} \mathrm{W}\right)$.

\section{Waterlogging Treatments}

\section{Experiment 1: Tolerance to Waterlogging Stress}

Waterlogging was performed by placing the $10 \mathrm{~L}$ (2.6 gal) inside larger $15 \mathrm{~L}$ (3.9 gal) plastic buckets and flooding with one of four solutions approximately $2.5 \mathrm{~cm}$ (1 in) above the growth media surface so that the shoots of the trees were still exposed to air. The solutions used were:

1. Tapwater;

2. Tapwater supplemented with $7.25 \mathrm{~g}(0.25 \mathrm{oz}) \mathrm{N}$ (supplied in the form of BOOST slow-release $\mathrm{N}$ fertilizer 29:7:9 $\mathrm{N}: \mathrm{P}: \mathrm{K}$; The Doggett Corporation) per liter of water;

3. Tapwater supplemented with $14.5 \mathrm{~g}(0.51 \mathrm{oz}) \mathrm{N}$ per liter of water; and

4. Tapwater supplemented with $29 \mathrm{~g}(1.02 \mathrm{oz}) \mathrm{N}$ per liter of water.

To achieve these $\mathrm{N}$ concentrations, BOOST was applied at $25 \mathrm{~g}(0.88 \mathrm{oz}), 50 \mathrm{~g}(1.8 \mathrm{oz})$, and $100 \mathrm{~g}(3.5 \mathrm{oz})$ per liter (0.26 gal) of water (treatments 2,3 , and 4$)$, respectively.

Inspecting daily and watering when necessary maintained this depth. Trees growing in freely drained pots drenched with tapwater were used as controls. Trees were kept under waterlogged conditions for 18 days, a time period when adverse effects on tree physiology of similar species were visibly observed
(Kreuzwieser et al. 2002). At the end of the 18-day waterlogging period, six trees per treatment were destructively harvested. To study the influence of $\mathrm{N}$ fertilization on the regenerative potential of the trees after waterlogging, excess water was decanted and six trees per treatment were left in freely drained growth media and watered when required for an additional 10 days, i.e., a total of 12 trees were used per treatment.

\section{Experiment 2: Recovery From Waterlogging Stress}

Waterlogging was performed by placing the $10 \mathrm{~L}$ ( 2.6 gal $)$ inside larger $15 \mathrm{~L}$ (3.9 gal) plastic buckets and flooding with tapwater only as outlined in Expt. 1. At the cessation of the 18-day waterlogging period, a number of physiological measurements were made on leaf tissue as measures of tree vitality. Immediately after measurements, trees were fertilized with $0.00,7.25 \mathrm{~g}(0.25$ oz), $14.5 \mathrm{~g}(0.51 \mathrm{oz})$, and $29 \mathrm{~g}(1.02 \mathrm{oz}) \mathrm{N}$ per liter of water and placed outdoors subject to natural weather conditions. Recovery rates were measured at two weekly intervals over a 6-week period. Ten trees per treatment were used and trees grown in freely drained growth media not subject to 18 days waterlogging acted as controls.

\section{Tree Vitality Measurements}

For all measurements, only fully expanded 21- to 28-day-old leaves were measured to keep the physiological age of the leaves comparable. Because leaf chlorophyll fluorescence, Soil Plant Analysis Development (SPAD), and photosynthetic rates measurements are noninvasive and nondestructive, all three measurements were made on the same leaf. Leaves were tagged to ensure only measurements were taken from the same leaf. During the recovery and regeneration period if abscission or mortality of tagged leaves occurred during the investigation, the nearest adjacent leaf was tagged for future measurements. Only leaves present at the onset of the experiment were measured throughout this investigation to record damage to and regeneration of the leaf photosynthetic apparatus during and after waterlogging treatment, respectively.

\section{Chlorophyll Fluorescence}

To characterize tree vitality, chlorophyll fluorescence values were recorded on five leaves from the crown of each tree. Measurements at ambient temperature were performed with a Handy Plant Efficiency Analyzer (PEA) chlorophyll fluorometer (Hansatech Instruments, King's Lynn, Norfolk, U.K.). During the measurement, the sample was shielded from ambient light by a clip system to reach a dark adapted state (30-min adaptation to the dark) and illuminated with $660 \mathrm{~nm}$ light from an LED source built into the fluorometer sensor. Continuous light excitation (at $2500 \mu \mathrm{mol} / \mathrm{m}^{2} / \mathrm{s}^{-1}$ ) was provided by an array of six lightemitting diodes focused on the leaf surface to provide homogeneous irradiation over a $4 \mathrm{~mm}$ (0.16 in) diameter leaf surface. A photosynthetic performance index (PI) based on an equation that combines the relationship of calculated relative number of reaction centers (RC) per light energy absorbed (ABS) and then multiplied by two expressions describing the yields of light trapping $(\phi p o)$ and subsequent electron transport $\left(\Psi_{0}\right)$ were used to quantify any effects on leaf tissue (Clark et al. 1998):

$$
\left.\mathrm{RC} / \mathrm{ABS} \times \phi \mathrm{po} /(1-\phi \mathrm{po}) \times \psi_{0} / 1-\psi_{0}\right)
$$

PI values have been shown to be a highly sensitive measure of leaf photosynthetic activities and provide an indirect measure of plant vitality (Clark et al. 2000; Percival and Fraser 2001). The Handy PEA automatically calculated PI values. 
In addition, the ABS, trapping (TRo), electron transport (ETo), and dissipation (DIo) flux per cross-section (CS) of photosystem II within leaf tissue were quantified at the cessation of the 18-day waterlogging period only (Expt. 1; Strasser and Strasser 1995). All energy fluxes were calculated and expressed diagrammatically as energy pipeline models (Figures 1 and 2) using the Biolyzer software package using data derived from leaf chlorophyll measurements (Maldonado Rodriguez 2002).

Photosynthetic $\mathrm{CO}_{2}$ Fixation

The light-induced $\mathrm{CO}_{2}$ fixation $(\mathrm{Pn})$ and stomatal conductance (g) was measured in predarkened (20 min) fully expanded leaves near the top of the canopy, generally the fourth leaf from the apex, using an Infra Red Gas Analyser (LCA-2 ADC BioScientific Ltd., Hoddesdon, Herts, U.K.). The irradiance on the leaves was 700 to $800 \mu \mathrm{mol} / \mathrm{m}^{-2}$ photosynthetically active radiation saturating with respect to $\mathrm{Pn}$; the velocity of the airflow was 1 $\mathrm{mL} / \mathrm{s}^{-1} / \mathrm{cm}^{-2}$ leaf area. Calculation of the photosynthetic rates was carried out according to Von Caemmerer and Farquhar (1981). Readings were taken at two weekly intervals and two

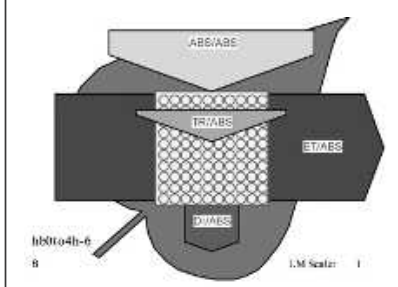

No waterlogging (control)

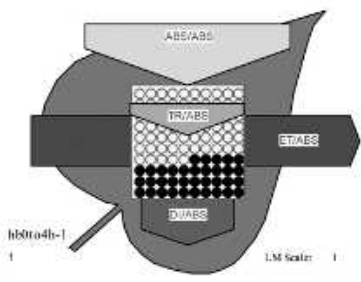

Waterlogging (7.25g N per litre water)

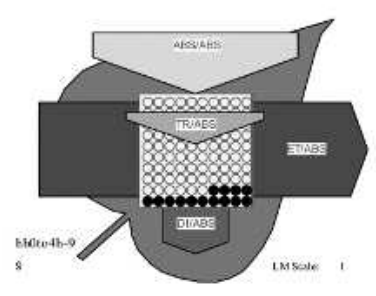

Waterlogging (29.0g N per litre water)

Figure 1. The influence of nitrogen $(N)$ fertilization on tolerance to waterlogging in English oak (Quercus robur L.) The relative magnitude of absorbance (ABS), trapping (TRO), electron transport (ETo), and dissipation (Dlo) flux per crosssection (CS) of photosystem II is shown by the width of the corresponding arrow. Inactivation of the reaction centers* per CS is shown in black. *Specialized pair of chlorophyll a molecules, which promote electron transfer within photosystem II responsible for the water-splitting and oxygenevolving reaction of photosynthesis.

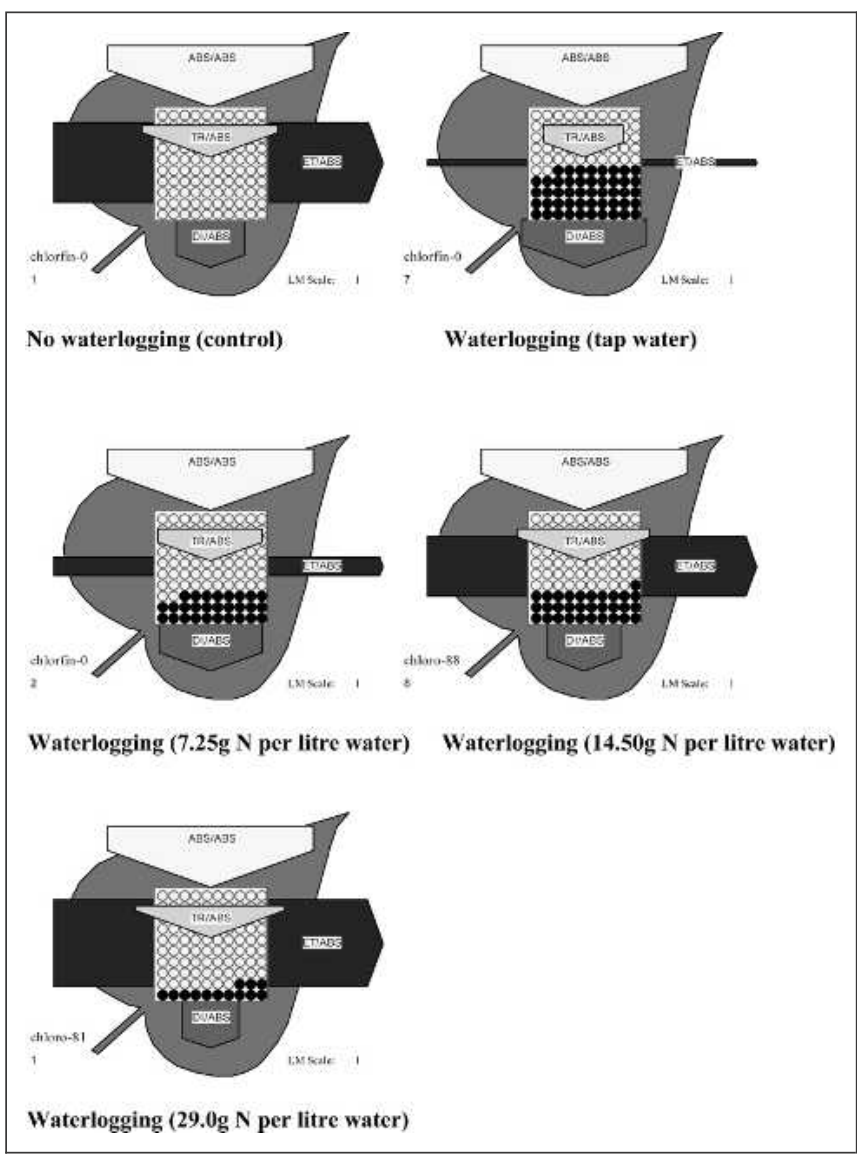

Figure 2. The influence of nitrogen $(\mathrm{N})$ fertilization on tolerance to waterlogging in European beech (Fagus sylvatica L.) The relative magnitude of absorbance (ABS), trapping (TRo), electron transport (ETo), and dissipation (Dlo) flux per cross-section (CS) of photosystem II is shown by the width of the corresponding arrow. Inactivation of the reaction centers ${ }^{*}$ per CS is shown in black. "Specialized pair of chlorophyll a molecules, which promote electron transfer within photosystem II responsible for the water-splitting and oxygen-evolving reaction of photosynthesis.

leaves per tree were selected for measurements. All photosynthetic measurements were taken in the early morning between 08:00 and 10:00 A.M. on clear or partly cloudy days.

\section{Chlorophyll Content}

A Minolta chlorophyll meter SPAD-502 (Spectrum Technologies, Inc., Plainfield, IL) was used. Chlorophyll was measured at the midpoint of the leaf next to the main leaf vein. Calibration was obtained by measurement of absorbance at 663 and $645 \mathrm{~nm}$ in a spectrophotometer (PU8800 Pye Unicam, Portsmouth, U.K.) after extraction with $80 \% \mathrm{v} / \mathrm{v}$ aqueous acetone (regression equation $=5.83+0.058 \mathrm{x} ; \mathrm{r}^{2}$ adjusted $\left.=0.87, P<0.01\right)$ (Lichtenthaler and Wellburn 1983). Chlorophyll content values were recorded on five leaves from the outer crown of each tree.

\section{Analysis of Leaf and Root Protein Concentrations}

Leaf and root protein concentrations were analyzed using a commercial assay (NRM Laboratories, Bracknell, U.K.). Fresh leaf and root material was powdered in liquid nitrogen. Aliquots of $20 \mathrm{mg}$ were added to $1.5 \mathrm{~mL}(0.05 \mathrm{fl} \mathrm{oz}) 0.1 \mathrm{M} \mathrm{KH}_{2} \mathrm{PO}_{4} /$ 
$\mathrm{K}_{2} \mathrm{HPO}_{4}, 0.5 \%$ (v/v) TRITON x-100, $\mathrm{pH} 7.8$ at $4^{\circ} \mathrm{C}\left(39.2^{\circ} \mathrm{F}\right)$. After centrifugation [ $\left.45 \mathrm{~min}, 16,000 \times \mathrm{g}, 4^{\circ} \mathrm{C}\left(39.2^{\circ} \mathrm{F}\right)\right]$, the clear supernatants were separated from low-molecular peptides by passing over a Sephadex G-25 column (Nap-5 Pharmacia; Waters HPLC Solutions, Centennial Park, Elstree, Hertfordshire, U.K.); $50 \mu \mathrm{L}$ of the eluted extract was analyzed in the protein assay based on a reaction of biuret reagent with proteins and a determination of the products at $562 \mathrm{~nm}$ by colorimetry.

\section{Foliar Nitrogen Content}

Leaf samples (six leaves per tree) were thoroughly washed and dried in a convection oven at $85^{\circ} \mathrm{C}\left(185^{\circ} \mathrm{F}\right)$ for $48 \mathrm{hr}$ before grinding through a $0.5 \mathrm{~mm}$ (0.02 in) cyclone mill (Retsch, Middlesborough, U.K.); $0.5 \mathrm{~g}(0.02 \mathrm{oz})$ samples were placed into $150 \mathrm{~mL}(4.5 \mathrm{fl} \mathrm{oz})$ volumetric flasks and digested in $20 \mathrm{~mL}(0.6$ fl oz) of 7:1 nitric/perchloric acid. After cooling, the solutions were brought to volume with deionized water and analyzed by inductively coupled plasma-emission spectroscopy elemental analysis. Nutrient values were expressed as grams per kilogram dry weight.

\section{Dry Weights and Leaf Area}

At the conclusion of the experiments, trees were destructively harvested. Leaf, shoot, and root dry weight were recorded after oven-drying at $85^{\circ} \mathrm{C}\left(185^{\circ} \mathrm{F}\right)$ for $48 \mathrm{hr}$. Leaf areas were quantified using a Delta-T area meter (Cambridge, England, U.K.).

\section{Experimental Design and Statistical Analysis}

For both Expts. 1 and 2, the design used was a completely randomized block design in which pots were rerandomized on a weekly basis. Trees were placed at $1 \mathrm{~m}(3.3 \mathrm{ft})$ spacing to prevent competition for light. Data for each species was analyzed independently by analysis of variance using the Genstat V (Committee of the Statistics Department, Rothamsted Experimental Station, Harpenden, Hertfordshire, U.K.) program for Windows after checks for normality and equal variance. When significant differences occurred, the means were separated by least signifi- cant difference test ( $\alpha=0.05$ significance level). In Expt. 2, because measurements over time were obtained from the same plant, the relationship between chlorophyll fluorescence and SPAD readings over time after $\mathrm{N}$ fertilization treatments was quantified using repeated measures analysis (quadratic regression).

\section{RESULTS}

Irrespective of treatment, no tree mortalities were recorded throughout this investigation.

\section{Experiment 1: Tolerance to Waterlogging Stress}

Regardless of species, at the cessation of an 18-day waterlogging period in the absence of $\mathrm{N}$ fertilizers, chlorophyll fluorescence PI, photosynthetic rates, leaf chlorophyll content, stomatal conductance, leaf and root protein concentration, and foliar $\mathrm{N}$ content values were significantly lower $(P<0.05)$ than trees grown in freely drained pots, i.e., controls (Table 1). The effects of 18-day waterlogging on growth measurements taken at the cessation of the waterlogging period and after a 10-day regeneration period did not significantly differ (Student's $t$ test). Consequently, values were pooled for statistical purposes (Table 3). In all cases, growth as measured by leaf area, shoot, root, and total plant dry weight of both test species was significantly lower $(P$ $<0.05$; Table 3 ) in trees waterlogged with tapwater compared with freely drained controls. Effects on the shoot:root ratio differed between species. English oak waterlogged with tapwater significantly enhanced the shoot:root ratio (Table 3); however, no significant effect on the shoot:root ratio was recorded in European beech (Table 3). Waterlogging in a slow-release $\mathrm{N}$ solution at $7.25 \mathrm{~g}(0.25 \mathrm{oz}) \mathrm{N}$ per liter $(0.26 \mathrm{gal})$ of water induced similar effects as those recorded by waterlogging in tapwater only, i.e., a significant reduction $(P<0.05)$ in the majority of tree vitality and growth parameters at the cessation of the 18-day waterlogging period and after a 10-day regeneration phase. Exceptions to this include chlorophyll fluorescence PI, leaf chlorophyll content, and foliar $\mathrm{N}$ content in English oak at the ces-

Table 1. The effects of 18 days waterlogging with and without nitrogen ( $\mathrm{N}$ ) fertilization on chlorophyll fluorescence (PI), photosynthetic $\mathrm{CO}_{2}$ fixation (Pn), leaf chlorophyll content, stomatal conductance leaf and root protein concentration, and foliar N content of English oak (Quercus robur L.) and European beech (Fagus sylvatica L.). ${ }^{2}$

\begin{tabular}{|c|c|c|c|c|c|c|c|}
\hline & PI & Pn & $\begin{array}{l}\text { Chlorophyll } \\
\text { content } \\
\text { (SPAD) }\end{array}$ & $\begin{array}{l}\text { Stomatal } \\
\text { conductance } \\
\text { (g) }\end{array}$ & $\begin{array}{l}\text { Leaf protein } \\
\text { concentration } \\
(\mathrm{mg} / \mathrm{g} \mathrm{FW})\end{array}$ & $\begin{array}{l}\text { Root protein } \\
\text { concentration } \\
\text { (mg/g FW) }\end{array}$ & $\begin{array}{l}\text { Foliar N } \\
\text { content } \\
(\%)\end{array}$ \\
\hline \multicolumn{8}{|l|}{ English oak } \\
\hline Tapwater & $1.0^{*}$ & $1.0^{*}$ & $28.3^{*}$ & $0.18 *$ & $24.3^{*}$ & $10.3^{*}$ & $1.81^{*}$ \\
\hline $7.25 \mathrm{~g}(0.25 \mathrm{oz}) \mathrm{N}$ & $3.3^{\mathrm{ns}}$ & $2.9 *$ & $34.6^{\mathrm{ns}}$ & $0.30 *$ & $33.7 *$ & $13.8 *$ & $2.25^{\mathrm{ns}}$ \\
\hline $14.5 \mathrm{~g}(0.51 \mathrm{oz}) \mathrm{N}$ & $3.9^{\mathrm{ns}}$ & $4.5^{\mathrm{ns}}$ & $42.5^{\mathrm{ns}}$ & $0.38^{\mathrm{ns}}$ & $43.1^{\mathrm{ns}}$ & $17.5^{\mathrm{ns}}$ & $2.78^{\mathrm{ns}}$ \\
\hline \multicolumn{8}{|l|}{ European beech } \\
\hline Control & 4.2 & 5.8 & 48.9 & 0.53 & 33.4 & 14.8 & 3.00 \\
\hline Tapwater & $0.7^{*}$ & $1.5^{*}$ & $18.7^{*}$ & $0.13 *$ & $18.7 *$ & $4.3^{*}$ & $1.23^{*}$ \\
\hline $7.25 \mathrm{~g}(0.25 \mathrm{oz}) \mathrm{N}$ & $1.4^{*}$ & $2.0^{*}$ & $21.8^{*}$ & $0.19 *$ & $20.5^{*}$ & $5.8^{*}$ & $1.40^{*}$ \\
\hline $14.5 \mathrm{~g}(0.51 \mathrm{oz}) \mathrm{N}$ & $2.8^{*}$ & $2.4^{*}$ & $30.2^{*}$ & $0.27 *$ & $26.5^{\mathrm{ns}}$ & $8.9^{*}$ & $2.59^{\mathrm{ns}}$ \\
\hline $29 \mathrm{~g}(1.02 \mathrm{oz}) \mathrm{N}$ & $3.1^{\mathrm{ns}}$ & $3.0^{*}$ & $27.6^{*}$ & $0.22 *$ & $27.2^{\mathrm{ns}}$ & $9.3^{*}$ & $2.38^{\mathrm{ns}}$ \\
\hline
\end{tabular}

${ }^{\mathrm{z}}$ Measurements were made immediately at the cessation of the waterlogging period. Trees were situated outdoors subject to natural climatic conditions.

$\mathrm{FW}=$ fresh leaf weight. PI and leaf chlorophyll content, values mean of mean of six trees, five leaves per tree. Pn and stomatal conductance values mean of mean of six trees, two leaves per tree. Leaf, root protein, and foliar $\mathrm{N}$ content mean of six trees, two leaves per tree were used and leaves pooled to provide a mean value per tree. * Significantly different from controls according to least significant difference (LSD) at $P<0.05$.

${ }^{\mathrm{ns}}=$ not significantly different from control value. 
Table 2. Chlorophyll fluorescence (PI), photosynthetic $\mathrm{CO}_{2}$ fixation (Pn), leaf chlorophyll content, stomatal conductance leaf and root protein concentration, and foliar nitrogen $(\mathrm{N})$ content of English oak (Quercus robur L.) and European beech (Fagus sylvatica L.) 10 days after 18 days waterlogging with and without $\mathrm{N}$ fertilization. ${ }^{\mathrm{z}}$

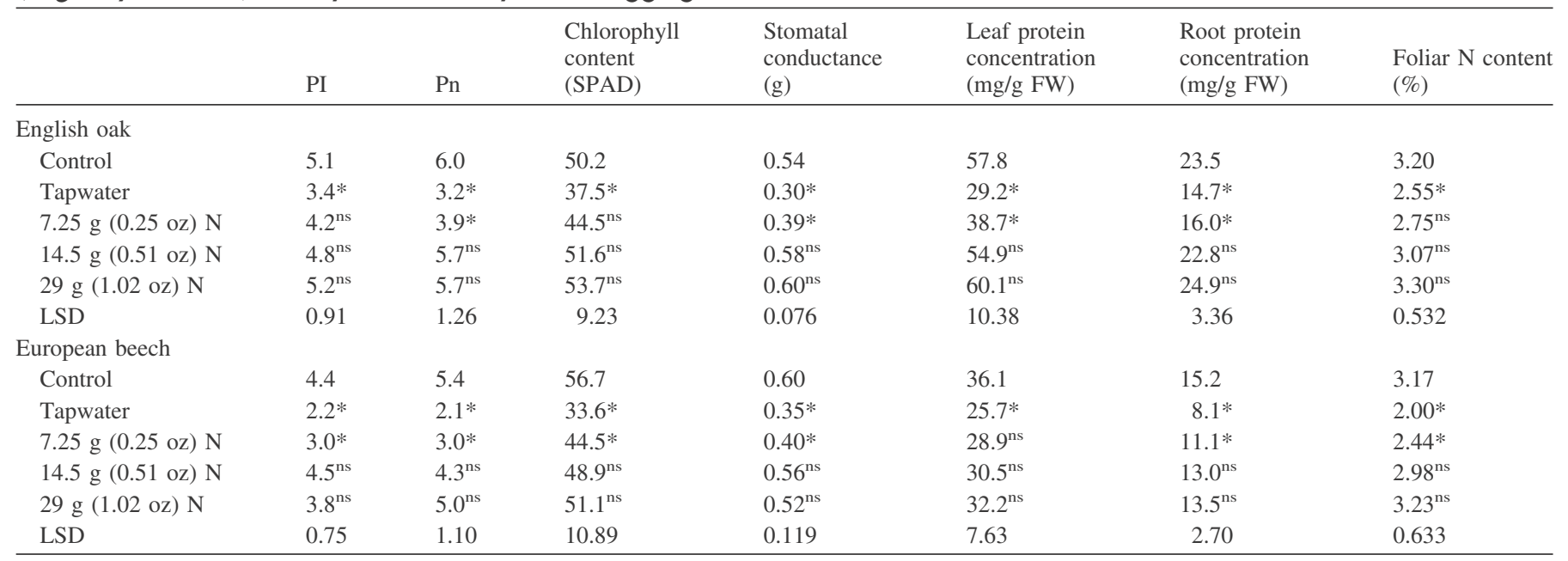

${ }^{\mathrm{z}}$ Trees were situated outdoors subject to natural climatic conditions.

$\mathrm{FW}=$ fresh leaf weight. PI and leaf chlorophyll content, values mean of mean of six trees, five leaves per tree. Pn and stomatal conductance values mean of mean of six trees, two leaves per tree. Leaf, root protein, and foliar $\mathrm{N}$ content mean of six trees, two leaves per tree were used and leaves pooled to provide a mean value per tree. *Significantly different from controls according to least significant difference (LSD) at $P<0.05$.

$\mathrm{ns}=$ not significantly different from control value.

sation of the 18-day waterlogging period and after 10 days regeneration in which values did not significantly differ from controls (Tables 1 and 2) and leaf protein content in European beech at the end of the 10-day regeneration period in which values did not significantly differ from controls (Table 2). English oak growth as measured by leaf area, shoot, root, total plant dry weight, and shoot:root ratio was significantly lower $(P<$ 0.05 ; Table 3 ) in trees waterlogged in a slow-release $\mathrm{N}$ solution [7.25 g ( $0.25 \mathrm{oz}) \mathrm{N}$ per liter (0.26 gal) of water] compared with freely drained controls. A similar effect was recorded in European beech with the exception of root and total plant dry weight that did not significantly differ from controls (Table 3).
Waterlogging in slow-release $\mathrm{N}$ solutions $14.5 \mathrm{~g}(0.51 \mathrm{oz})$ or greater $\mathrm{N}$ per liter ( $0.26 \mathrm{gal})$ of water had a marked impact on tolerance to and regeneration from waterlogging irrespective of species (Tables 1-3). With few exceptions, chlorophyll fluorescence PI, photosynthetic rates, leaf chlorophyll content, stomatal conductance, leaf and root protein concentration, foliar $\mathrm{N}$ content, leaf area, shoot, root, and total plant dry weight did not significantly differ from trees grown in freely drained pots (Table 2). Such an effect is especially pronounced in English oak in which recorded values were lower than freely drained controls but in no instances were they significantly so (Table 2). In the case of European beech, significant $(P<0.05)$ reductions in

Table 3. The effects of waterlogging with and without nitrogen (N) fertilization on growth of English oak (Quercus robur L.) and European beech (Fagus sylvatica L.). ${ }^{2}$

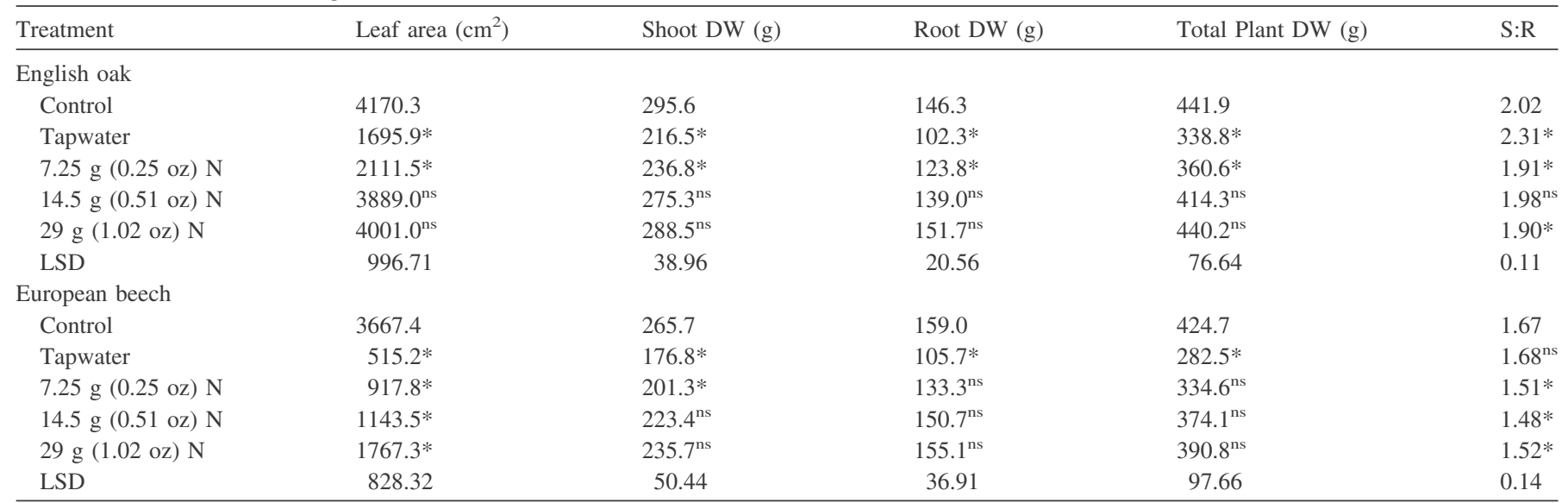

${ }^{z}$ Data presented is combined from measurements taken immediately at the cessation of the end of an 18-day waterlogging period and 10 days after the 18-day waterlogging treatment. Trees were situated outdoors subject to natural climatic conditions.

$\mathrm{DW}=$ dry weight; shoot DW = leaf and shoot DW combined; S:R = shoot:root ratio. All values mean of 12 trees. Six trees were harvested at the cessation of 18 days waterlogging and six trees harvested 10 days later. No significant differences (Student's $t$ test) were found between dry weights at both time periods.

* Significantly different from controls according to least significant difference (LSD) at $P<0.05$.

${ }^{\mathrm{ns}}=$ not significantly different from control value. 
values were made at the cessation of the 18-day waterlogging period only (Table 1$)$. After 10 days regeneration with one exception [significantly $(P<0.05)$ reduced leaf area], no significant effects were recorded compared with European beech trees grown in freely drained pots, although values were constantly lower (Table 3). Waterlogging in slow-release N solutions 14.5 $\mathrm{g}(0.51 \mathrm{oz})$ or greater $\mathrm{N}$ per liter $(0.26 \mathrm{gal})$ of water significantly $(P<0.05)$ reduced the shoot:root ratio in the majority of cases (Table 3) indicating greater resource allocation in favor of roots over shoots in both tree species.

\section{Energy Fluxes per Leaf Cross-section of Photosystem II}

The effect of 18 days waterlogging on ABS, TRo, and ETo flux per CS of photosystem II is shown diagrammatically (Figures 1 and 2). At the cessation of the 18-day waterlogging period, light ABS, TRo, and ETo flux per CS of photosystem II were reduced by $10.1 \%$ and $5.3 \%, 20.0 \%$ and $361 \%$ and $49.2 \%$ and $90.1 \%$ compared with control values in English oak and European beech, respectively (Figures 1 and 2). Irrespective of species, least reductions in ABS, TRo, and ETo fluxes per CS of photosystem II were associated with $\mathrm{N}$ fertilization applied $14.5 \mathrm{~g}$ $(0.51 \mathrm{oz})$ or greater $\mathrm{N}$ per liter $(0.26 \mathrm{gal})$ of water to the waterlogging solution. Dissipation (DIo) fluxes per CS of photosystem II were increased by $37.5 \%$ and $63.6 \%$ of the control values in English oak and European beech, respectively (Figures 1 and 2). English oak was identified as the most resistant to waterlogginginduced damage with lower percent reductions in light ABS, TRo, and ETo flux per CS of photosystem II compared with European beech indicating less damage to the leaf photosynthetic system as a result of 18 days waterlogging (Figures 1 and 2). Likewise, energy dissipation fluxes per CS of photosystem II were lower in English oak compared with European beech. Higher dissipation fluxes per CS of photosystem II indicate a switch from photochemical (light energy absorbed used to provide the chemical energy for $\mathrm{CO}_{2}$ fixation) to nonphotochemical work (heat dissipation), a response indicative of increased respiration resulting in impairment of the leaf photosynthetic system. Irrespective of species, least reductions in DIo fluxes per $\mathrm{CS}$ of photosystem II were associated with $\mathrm{N}$ fertilization applied $14.5 \mathrm{~g}(0.51 \mathrm{oz})$ or greater $\mathrm{N}$ per liter $(0.26 \mathrm{gal})$ of water to the waterlogging solution. In both English oak and European beech, increasing $\mathrm{N}$ content of the waterlogging solution lowered the number of reaction centers per CS of photosystem II that became inactivated. Higher inactivation of the reaction centers associated with non-N-supplemented English oak and European beech indicates an altered metabolic state from photochemical work to nonphotochemical energy dissipation.

\section{Experiment 2: Recovery From Waterlogging Stress}

The pattern of recovery over the next 6 weeks after 18 days waterlogging on chlorophyll fluorescence PI, photosynthetic rates, leaf chlorophyll content, and stomatal conductance is shown for English oak and European beech (Table 4). In addition, the pattern of recovery is shown diagrammatically for both species with respect to leaf chlorophyll content (Figures 3 and 4). Irrespective of treatment, with or without $\mathrm{N}$ fertilization, all four parameters began to recover after waterlogging as quantified by quadratic regression analysis to compare the rate of recovery over the next 6 weeks (Table 4). In both English oak and European beech, all $\mathrm{N}$-fertilized trees were the most capable of recovery as reflected by higher regression " $b$ " values with respect to PI, photosynthetic rates, leaf chlorophyll content, and stomatal conductance (Table 4). Greatest recovery rates were recorded in both species fertilized with slow-release N $14.5 \mathrm{~g}(0.51 \mathrm{oz})$ or greater $\mathrm{N}$ per liter $(0.26 \mathrm{gal})$ of water. Such responses in $\mathrm{N}$ fertilized trees are associated with enhanced recovery of leaf photosynthetic integrity, improved photosynthetic efficiency, reduced damage of the chlorophyll molecule, and enhanced stomatal function compared with recovery rates of non-N-fertilized trees. Recovery as determined by chlorophyll fluorescence PI, photosynthetic rates, leaf chlorophyll content, and stomatal conductance rates of waterlogged trees treated with an $\mathrm{N} 14.5 \mathrm{~g}$ $(0.51 \mathrm{oz})$ or greater per liter $(0.26 \mathrm{gal})$ of water ranged from $30 \%$ to $50 \%$ higher than non- $\mathrm{N}$-fertilized trees (Table 4 ). At the cessation of the 6-week recovery period, all values were comparable if not higher than controls (nonwaterlogged trees; Figures 3 and 4) indicating full functioning and regeneration of the leaf photosynthetic apparatus. In all cases, non-N-fertilized had the least capacity for recovery after the cessation of 18 days waterlogging. Chlorophyll fluorescence PI, photosynthetic rates, leaf chloro-

Table 4. Nitrogen $(\mathrm{N})$ fertilization enhanced recovery of leaf chlorophyll fluorescence (PI), photosynthetic $\mathrm{CO}_{2}$ fixation (Pn), chlorophyll content, and stomatal conductance of containerized English oak (Quercus robur L.) and European beech (Fagus sylvatica L.) placed outdoors with time (6 weeks) based on quadratic regression analysis after 18 days waterlogging.

\begin{tabular}{|c|c|c|c|c|c|c|c|c|}
\hline nent & PI & & Pn & & $\begin{array}{l}\text { Chlorophyll content } \\
\text { (SPAD) }\end{array}$ & & Stomatal conductance & \\
\hline Control & $\mathrm{y}=4.80+0.10+0.00$ & 0.96 & $\mathrm{y}=5.57-0.34+0.08$ & 0.93 & $\mathrm{y}=48.11+2.70-0.46$ & 0.95 & $\mathrm{y}=0.55-0.04+0.01$ & 0.98 \\
\hline $7.25 \mathrm{~g}(0.25 \mathrm{oz}) \mathrm{N}$ & $\mathrm{y}=0.73+0.52+0.03$ & 0.89 & $\mathrm{y}=1.24+0.27+0.06$ & 0.81 & $\mathrm{y}=26.76+3.78-0.20$ & 0.78 & $\mathrm{y}=0.16+0.05-0.00$ & 0.98 \\
\hline $14.5 \mathrm{~g}(0.51 \mathrm{oz}) \mathrm{N}$ & $\mathrm{y}=1.01+1.82-0.19$ & 0.85 & $\mathrm{y}=1.26+0.58+0.03$ & 0.77 & $y=26.82+4.01-0.08$ & 0.88 & $\mathrm{y}=0.15+0.11-0.01$ & 0.91 \\
\hline $29 \mathrm{~g}(1.02 \mathrm{oz}) \mathrm{N}$ & $\mathrm{y}=0.95+1.70-0.14$ & 0.90 & $\mathrm{y}=1.08+1.81-0.16$ & 0.76 & $\mathrm{y}=27.73+2.78+0.18$ & 0.91 & $\mathrm{y}=0.17+0.06+0.00$ & 0.90 \\
\hline Tapwater & $\mathrm{y}=0.79+0.30+0.04$ & 0.82 & $\mathrm{y}=1.28+0.14+0.06$ & 0.81 & $\mathrm{y}=18.50+1.50+0.51$ & 0.76 & $\mathrm{y}=0.13+0.04+0.00$ & 0.84 \\
\hline $7.25 \mathrm{~g}(0.25 \mathrm{oz}) \mathrm{N}$ & $\mathrm{y}=0.79+0.82-0.04$ & 0.88 & $\mathrm{y}=1.35+0.67-0.03$ & 0.80 & $\mathrm{y}=18.52+2.75+0.38$ & 0.81 & $\mathrm{y}=0.15+0.04-0.01$ & 0.87 \\
\hline $14.5 \mathrm{~g}(0.51 \mathrm{oz}) \mathrm{N}$ & $\mathrm{y}=0.85+1.93-0.19$ & 0.78 & $\mathrm{y}=1.27+1.33-0.11$ & 0.69 & $\mathrm{y}=17.35+3.93+0.44$ & 0.65 & $\mathrm{y}=0.12+0.07+0.01$ & 0.80 \\
\hline $29 \mathrm{~g}(1.02 \mathrm{oz}) \mathrm{N}$ & $\mathrm{y}=0.79+1.74-0.16$ & 0.75 & $\mathrm{y}=1.11+1.88-0.18$ & 0.71 & $\mathrm{y}=18.25+6.13+0.19$ & 0.81 & $\mathrm{y}=0.13+0.07+0.01$ & 0.79 \\
\hline
\end{tabular}

PI and leaf chlorophyll content, values mean of mean of ten trees, five leaves per tree. Pn and stomatal conductance mean of ten trees, two leaves per tree.

Regression: y, leaf PI, Pn, chlorophyll content, and stomatal conductance; a, leaf PI, Pn, chlorophyll content, and stomatal conductance (estimated calculated intercept); b, rate of leaf PI, Pn, chlorophyll content, and stomatal conductance with time (T); c, = rate of change of leaf PI, Pn, chlorophyll content, and stomatal conductance. 


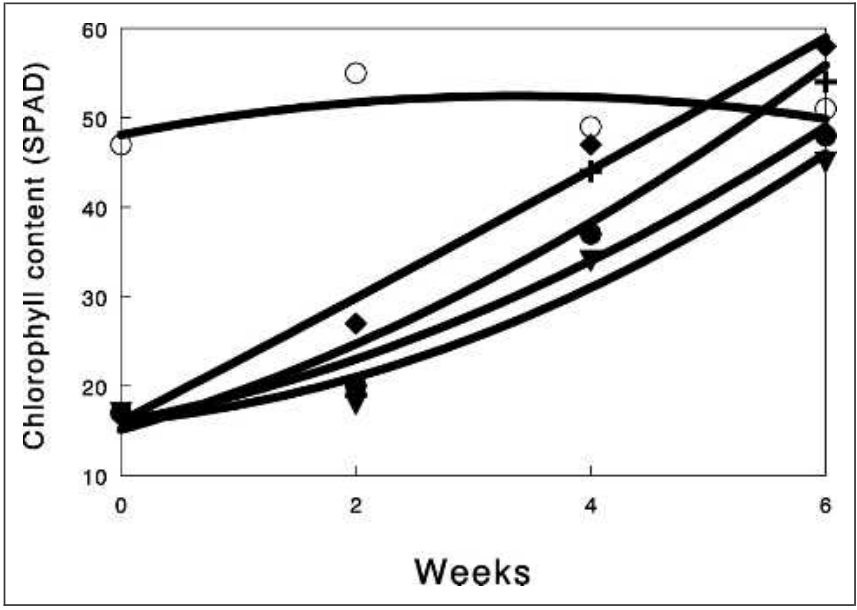

Figure 3. The influence of nitrogen $(N)$ fertilization on time course recovery of leaf chlorophyll content of English oak (Quercus robur L.) after 18 days waterlogging. $\mathrm{O}=$ no waterlogging (control); $\nabla=$ waterlogging (tapwater); $\bullet=$ waterlogging (7.25 g (0.25 oz) N per liter water); + = waterlogging ( $14.5 \mathrm{~g}(0.51 \mathrm{oz}) \mathrm{N}$ per liter water); $\diamond=$ waterlogging (29 g (1.02 oz) N per liter water).

phyll content, and stomatal conductance values of English oak and European beech placed in freely drained growth media remained constant over the 18-day experimental period (Table 4; Figures 1 and 2). None of the treatments used in this investigation altered the ratio of chlorophyll $a: b$ in English oak (3.04 to 3.25) or European beech (3.11 to 3.40; data not shown). During the 6-week recovery phase, new leaf formation was observed at approximately weeks 4 through 6 on both control and $\mathrm{N}$ fertilized trees. However, at the cessation of the 6-week recovery period, irrespective of $\mathrm{N}$ treatment and species, all waterlogged trees had significantly $(P<0.05)$ less leaf area compared with freely drained controls (Table 5). In the case of English oak, all $\mathrm{N}$-fertilized trees [7.25 g $(0.25 \mathrm{oz}), 14.5 \mathrm{~g}(0.51 \mathrm{oz})$ and $29 \mathrm{~g}$ $(1.02 \mathrm{oz}) \mathrm{N}$ per liter $(0.26 \mathrm{gal})$ of water] had lower shoot, root,

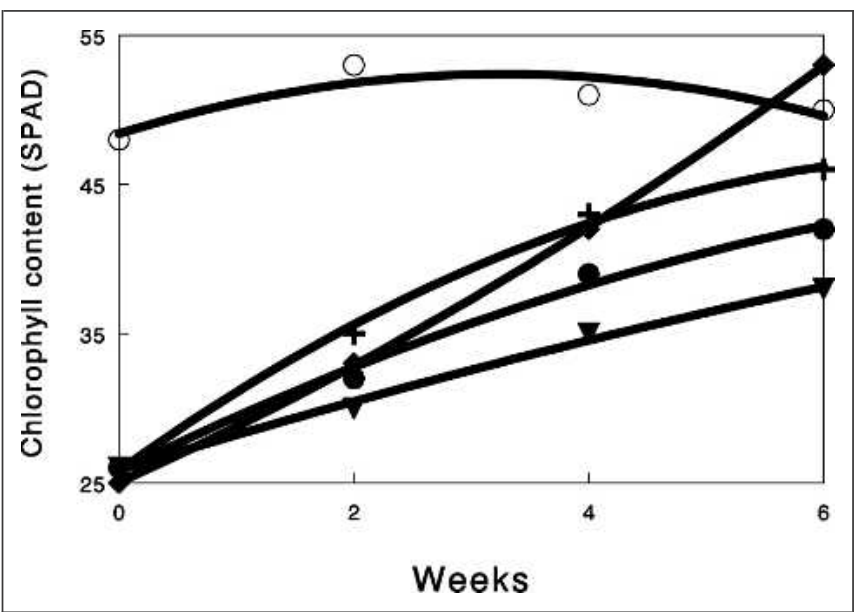

Figure 4. The influence of nitrogen $(\mathrm{N})$ fertilization on time course recovery of leaf chlorophyll content of European beech (Fagus sylvatica L.) after 18 days waterlogging. $\mathrm{O}=$ no waterlogging (control); $\boldsymbol{\nabla}=$ waterlogging (tapwater); 0 = waterlogging (7.25 g (0.25 oz) N per liter water); + = waterlogging (14.5 g (0.51 oz) N per liter water); $\diamond$ = waterlogging (29 g (1.02 oz) N per liter water). total plant dry weight, and shoot:root ratios compared with control trees, but these data were not significantly so. In the case of European beech, none fertilized and $\mathrm{N}$-fertilized trees at $7.25 \mathrm{~g}$ $(0.25 \mathrm{oz}) \mathrm{N}$ per liter $(0.26 \mathrm{gal})$ of water had significantly $(P<$ $0.05)$ lower shoot, root, and total plant dry weights compared with control trees (Table 5). Shoot, root, and total plant dry weights in European beech fertilized at $\mathrm{N}$ concentrations $14.5 \mathrm{~g}$ $(0.51 \mathrm{oz})$ or greater $\mathrm{N}$ per liter $(0.26 \mathrm{gal})$ of water did not significantly differ from controls with one exception: shoot dry weight of trees fertilized with $14.5 \mathrm{~g}(0.51 \mathrm{oz}) \mathrm{N}$ per liter $(0.26$ gal) of water in which values were significantly $(P<0.05)$ less than controls. Irrespective of treatment, with and without $\mathrm{N}$, shoot:root ratios in waterlogged European beech were reduced but not significantly so compared with nonwaterlogged controls (Table 5).

\section{DISCUSSION}

\section{Experiment 1: Tolerance to Waterlogging Stress}

English oak typically grows in Pinus-Quercus robur L. forests as well as in mixed deciduous forests with a adequate water supply or in lowland forests (Kreuzwieser et al. 2002) where it is frequently exposed to intermittent flooding and therefore considered moderate flooding-tolerant (Ellenberg 1986). By contrast, European beech (Fagus sylvatica L.) does not inhabit wet sites or riparian forests and is classified as a highly flooding-sensitive species (Gorzelak 2000). One feature of waterlogging tolerance in tree species is carbon reallocation from roots to shoots as indicated by an increased shoot:root matter ratio. Such an alteration acts as an effective physiological strategy in decreasing the amount of respiring root tissue and therefore the oxygen demand of the root system for aerobic respiration (Naidoo and Naidoo 1992; Basra and Basra 1997). Resource allocation from belowto aboveground occurs under waterlogged conditions in both wetland and nonwetland plant species (Mendelssohn and Postek 1982; Huang et al. 1994a, 1994b). At the cessation of an 18-day waterlogging period, such a physiological response is shown in English oak (waterlogging-intermediate) flooded with tapwater in which the shoot:root ratio increased from 2.02 to 2.31, but not in European beech (waterlogging-sensitive) in which no effects on the shoot:root ratio were recorded compared with trees grown in freely drained growth media. Contrary to this, waterlogging both English oak and European beech in the presence of $\mathrm{N}$ reduced the shoot:root ratio indicating a carbon reallocation from shoots to roots. Proliferation of tree root systems in a moist N-rich environment has been demonstrated by Dobson (1995), whereas work by Majdi and Kangas (1997) concluded fine root turnover of forest trees increased exponentially with $\mathrm{N}$ availability. Work by Mackie-Dawson et al. (1998) using Sycamore (Acer pseudoplatanus L.) and Sitka spruce [Picea sitchensis (Bong.) Carr.] as test species reported provision of $\mathrm{N}$ stimulated greater root growth compared with non-N-fertilized trees with increased root mass and root diameter with $\mathrm{N}$ supply. Gilbertson et al. (1985) demonstrated that addition of $\mathrm{N}$ to severely $\mathrm{N}$ deficient china clay wastes increased root extension of birch resulting in a tenfold exploitation of soil volume compared with non-N-fertilized controls.

The portion of $\mathrm{N}$ uptake by plants amounts to greater than $80 \%$ of total ion uptake by the root system. Consequently, reduction of $\mathrm{N}$ uptake can cause significant losses of tree vitality (Marschner 1995). According to Kendle and Sherman (2004), N shortage is recognized as a primary symptom of waterlogged or 
Table 5. The influence of nitrogen (N) fertilization on growth of English oak (Quercus robur L.) and European beech (Fagus sylvatica L.) placed outdoors subject to natural climatic conditions at week six after the cessation of an 18-day waterlogging period.

\begin{tabular}{|c|c|c|c|c|c|}
\hline Treatment & Leaf area & Shoot DW & Root DW & Total Plant DW & $\mathrm{S}: \mathrm{R}$ \\
\hline Control & 4324.8 & 312.4 & 156.7 & 469.1 & 1.99 \\
\hline $7.25 \mathrm{~g}(0.25 \mathrm{oz}) \mathrm{N}$ & $2761.0 *$ & $251.4^{\mathrm{ns}}$ & $134.3^{\text {ns }}$ & $385.7^{\mathrm{ns}}$ & $1.89^{\mathrm{ns}}$ \\
\hline $14.5 \mathrm{~g}(0.51 \mathrm{oz}) \mathrm{N}$ & $3324.6 *$ & $280.9^{\text {ns }}$ & $149.9^{\text {ns }}$ & $430.8^{\text {ns }}$ & $1.87^{\mathrm{ns}}$ \\
\hline $29 \mathrm{~g}(1.02 \mathrm{oz}) \mathrm{N}$ & $3465.7 *$ & $286.3^{\text {ns }}$ & $156.3^{\text {ns }}$ & $442.6^{\text {ns }}$ & $1.83^{\mathrm{ns}}$ \\
\hline Control & 3881.9 & 289.0 & 166.9 & 455.9 & 1.73 \\
\hline Tapwater & $676.9 *$ & $191.2 *$ & $112.4 *$ & $303.6^{*}$ & $1.70^{\mathrm{ns}}$ \\
\hline $7.25 \mathrm{~g}(0.25 \mathrm{oz}) \mathrm{N}$ & $889.4 *$ & $207.8^{*}$ & $126.1 *$ & $333.9^{*}$ & $1.62^{\mathrm{ns}}$ \\
\hline $14.5 \mathrm{~g}(0.51 \mathrm{oz}) \mathrm{N}$ & $1271^{*}$ & $223.8^{*}$ & $145.3^{\mathrm{ns}}$ & $369.1^{\mathrm{ns}}$ & $1.54^{\mathrm{ns}}$ \\
\hline $29 \mathrm{~g}(1.02 \mathrm{oz}) \mathrm{N}$ & $1456^{*}$ & $240.9^{\text {ns }}$ & $150.6^{\mathrm{ns}}$ & $391.5^{\mathrm{ns}}$ & $1.60^{\mathrm{ns}}$ \\
\hline LSD & 1028.70 & 63.87 & 39.47 & 107.37 & 0.217 \\
\hline
\end{tabular}

$\mathrm{DW}=$ dry weight; shoot DW = leaf and shoot DW combined; S:R = shoot:root ratio. All values mean of ten trees.

*Significantly different from controls according to least significant difference (LSD) at $P<0.05$.

${ }^{\mathrm{ns}}=$ not significantly different from control value.

anaerobic soils. Foliar $\mathrm{N}$ accumulation was restricted more by waterlogging in tapwater compared with waterlogging in the presence of $\mathrm{N}$ in both test species. Consequently, increased $\mathrm{N}$ supply to the waterlogged rooting medium may have improved foliar $\mathrm{N}$ content status for both species that contributed to the superior growth of waterlogged plants under higher $\mathrm{N}$ regimes (Huang et al. 1994b). As a result of the impact of waterlogging on $\mathrm{N}$ uptake, longer periods of waterlogging can influence $\mathrm{N}$ nutrition of trees that may be manifest in the concentration of leaf and root protein (Bertani and Reggiani 1991). Concomitant with increased foliar $\mathrm{N}$ content, both leaf and root protein content were enhanced in English oak and European beech, a result in agreement with work by Bartels (2001) who studied the influence of waterlogging on the root protein content of English oak and Common ash (Fraxinus excelsior L.). Increased protein concentrations as a consequence of increased $\mathrm{N}$ availability and uptake may prove an important survival strategy in response to prolonged waterlogging for the biosynthesis of anaerobicinduced enzymes such as pyruvate decarboxylase, lactate dehydrogenase, and alcohol dehydrogenase (Vartapetian and Jackson 1997). Enhanced protein content may also prove essential for the stimulation of glycolysis (Ricard et al. 1998). In flood-intolerant plants when oxygen fails to reach the root tissue, glucose is metabolized for energy with the end product being alcohol that is, in turn, toxic to plants. Waterlogging-tolerant species possess the ability to form malate, a less toxic compound, as the end product of glucose breakdown. In addition, the influence of $\mathrm{N}$ fertilizers supporting protein synthesis during periods of prolonged waterlogging may be relevant to the structural integrity of the root tonoplast membrane preventing rupture and collapse (Huang 1997). A role for $\mathrm{N}$ positively affecting the lipid composition of membranes and root aerenchyma formation during prolonged waterlogging has been discussed by Basra and Basra (1997).

Besides the energy limitation attributable to a switch from respiration to fermentation, the reduced foliar $\mathrm{N}$ in trees waterlogged with tapwater may result from reduced transpiration as indicated by lower stomatal conductance $(\mathrm{g})$ values. A reduction of xylem flow is known to repress $\mathrm{N}$ uptake in trees (GeBler et al. 2002). If photosynthetic rates are used as an indicator for tree growth (Isebrands et al. 1988), then reduced $\mathrm{CO}_{2}$ assimilation caused by stomatal closure limiting intercellular $\mathrm{CO}_{2}$ concentration during flooding suggests reductions in growth (Gardiner and Hodges 1996). $\mathrm{N}$ has been suggested to contribute to osmotic adjustment to facilitate stomatal opening during periods of water stress (Talouizite and Champigny 1988). Results of this investigation and that of Farrar et al. (1989) indicate stomatal conductance is enhanced by the addition of $\mathrm{N}$ fertilizers to the waterlogged medium because a broad correlation is observed between photosynthetic rates and stomatal conductance with higher concentrations of $\mathrm{N}$ within the waterlogging solution promoting higher rates of photosynthesis and stomatal conductance in both English oak and European beech.

Chlorophyll content in plants waterlogged without the addition of $\mathrm{N}$ fertilizers was reduced significantly irrespective of species. Similar reductions of chlorophyll content have been observed in other tree species after prolonged flooding (Gravatt and Kirby 1998). Supplying N fertilizers to waterlogged plants increased the chlorophyll level to one not significantly different from trees grown in freely drained growth media in the case of English oak. In European beech, although chlorophyll levels were significantly lower than trees grown in freely drained growth media, trees supplemented with $\mathrm{N}$ had approximately $50 \%$ more foliar chlorophyll than non-N-supplemented trees. Higher foliar chlorophyll content would account for enhanced Pn and chlorophyll fluorescence PI values as a measure of photosynthetic efficiency in N-supplemented trees because chlorophyll is the major cell of photosynthetic activity within higher plants (Lawlor 2001). Previous work has shown that in hardy or stress-tolerant deciduous and evergreen trees, environmental tolerance is associated with increased rates of photosynthesis with greater rates occurring in hardier varieties than in less hardy ones (Levitt 1980). Additional carbon capture also supplies carbon for osmotic adjustment, thereby promoting turgor maintenance, stomatal opening, and further photosynthesis (Tan et al. 1992). Least reductions in light absorbance, trapping, and electron transport energy fluxes per CS of photosystem II were associated with $14.5 \mathrm{~g}(0.51 \mathrm{oz})$ or greater $\mathrm{N}$ per liter $(0.26 \mathrm{gal})$ of water in 
both English oak and European beech. Consequently, if the photosynthetic system remains intact during periods of waterlogging; manifest by higher light absorbance, trapping, and electron transport values, then the plant has the ability to repair damaged tissue and grow and survive after the cessation of stress. Greater energy dissipation fluxes and inactivation of reaction centers per CS of photosystem II associated with non-N-supplemented English oak and European beech indicate a switch from photochemical work (light energy absorbed by leaf chlorophyll pigments to provide the chemical energy for $\mathrm{CO}_{2}$ fixation) to nonphotochemical work, i.e., heat dissipation, a response indicative of breakdown of the leaf photosynthetic system (Lawlor 2001).

Besides the flexibility during stress periods, the regeneration of normal functioning of plant physiological processes after the stressor disappearance is crucial for survival (Kreuzwieser et al. 2002). After application of $\mathrm{N}$ fertilizers at concentrations $14.5 \mathrm{~g}$ $(0.51 \mathrm{oz})$ or greater $\mathrm{N}$ per liter $(0.26 \mathrm{gal})$ of water to the waterlogging solution, most physiological parameters used in this investigation of measures of tree vitality (chlorophyll fluorescence PI, photosynthetic rates, leaf chlorophyll content, stomatal conductance, leaf, root protein concentration, foliar $\mathrm{N}$ content) were comparable to freely drained controls, indicating repairable damage to whole tree physiology 10 days after the cessation of 18 days waterlogging. In the case of non-N-supplemented trees or those supplemented with $7.25 \mathrm{~g}(0.25 \mathrm{oz}) \mathrm{N}$ per liter $(0.26 \mathrm{gal})$ of water, values in most instances were significantly lower than trees grown in freely drained growth media indicating impairment or partial functioning of a range of physiological processes.

Improvements in the range of physiological measurements discussed previously may account for increased growth as measured by leaf area, shoot, root, and total plant dry weight in trees supplemented with $\mathrm{N}$ fertilizers at concentrations $14.5 \mathrm{~g}(0.51$ $\mathrm{oz})$ or greater $\mathrm{N}$ per liter $(0.26 \mathrm{gal})$ of water at the cessation of 18 days waterlogging and after a 10-day regeneration period. In both tree species, the most pronounced effect of waterlogging on growth was reduced leaf area (Gardiner and Hodges 1996). Leaf abscission caused by waterlogging in the absence and presence of $\mathrm{N}$ was observed in both tree species, although less so with increasing $\mathrm{N}$ concentration. Leaf area has been shown to be a significant contributor to growth under waterlogging stress because leaves are the major photosynthetic organ responsible for carbohydrate production necessary for the growth and repair of damaged tissue (Farrell et al. 1996).

In conclusion, responses recorded in this study indicate the adverse effect of waterlogging can be significantly offset by increasing the $\mathrm{N}$ supply to the rooting medium. Marked improvements in growth and alterations in the shoot:root ratio for both English oak and European beech by increasing $\mathrm{N}$ supply indicates there was a nutrient-induced alteration in waterlogging tolerance beneficial to both tree species.

\section{Experiment 2: Recovery From Waterlogging Stress}

Few investigations have recorded the influence of $\mathrm{N}$ fertilization on the recovery phase of trees from waterlogging focusing heavily on short term in situ measurements to quantify damage during the waterlogging process (Mclean 1993). Such experimentation is limited because deciduous trees possess the ability to recover from severe environmental stress with limited long- term effects, for example, by refoliation, to replenish depleted nutrient reserves (Hermes 2001). Despite severe damage to the leaf photosynthetic apparatus as measured by reduced photosynthetic rates, chlorophyll fluorescence, stomatal conductance, and leaf chlorophyll content at day 18 after waterlogging, both test species showed symptoms of recovery by week 6 . Regardless of species, highest rates of recovery were associated in trees fertilized with $14.5 \mathrm{~g}(0.51 \mathrm{oz})$ or greater $\mathrm{N}$ per liter $(0.26 \mathrm{gal})$ of water. At the cessation of the 6-week recovery phase, photosynthetic rates, photosynthetic efficiency, stomatal conductance, and leaf chlorophyll content were in most cases higher than freely drained controls (Figures 3 and 4 ) and ranged from 20\% to 50\% higher than non-N-treated trees, indicating regeneration and full functioning of the leaf photosynthetic system and chlorophyll molecules. The extent of resistance to stress has been shown to be closely related to a plant's capacity for recovery with genotypes that rebound to original or near original physiological levels most likely to survive and tolerate stress episodes compared with those that do not or are slower to recover (Aguilera et al. 1997).

Although tree vitality measurements were comparable with freely drained controls at the cessation of the 6-week recovery phase, marked effects on growth were recorded with greater growth associated with enhanced $\mathrm{N}$ fertilization. During the 18day waterlogging period, heavy leaf abscission was recorded in both species. At the cessation of the 6-week recovery phase, higher leaf areas were constantly recorded in $\mathrm{N}$-fertilized trees compared with non-fertilized ones. Work by Farrell et al. (1996) using Eucalyptus camaldulensis and that of Pregitzer et al. (1990) using Populus clones reported that leaf production rates were important variables influencing growth under waterlogging stress. More leaves produced during the recovery period as stimulated by greater abundance of $\mathrm{N}$ enhanced total leaf area and subsequent photosynthetic area. In turn, growth as measured by total tree dry weight has been positively correlated with net photosynthetic rates (Ort and Boyer 1985).

In conclusion, root deoxygenation caused by prolonged waterlogging is recognized as a major factor contributing to tree decline in urban landscapes (Hitchmough 1994). Applications of $\mathrm{N}$ fertilizers after waterlogging stress would be of benefit to improve tree recovery rates and growth of English oak and European beech. From a practical point of view, N fertilization 14.5 $\mathrm{g}(0.51 \mathrm{oz})$ or greater $\mathrm{N}$ per liter $(0.26 \mathrm{gal})$ of water is tentatively suggested based on the results of this study.

\section{LITERATURE CITED}

Aguilera, C., C.M. Stirling, and S.P. Long. 1997. Genotypic variation within Zea mays for susceptibility to and rate of recovery from chillinduced photoinhibition of photosynthesis. Physiologia Plantarum 106:429-436.

Bartels, D. 2001. Untersuchungen zum Stickstoffhaushalt von Esche (Fraxinus excelsior L.) und Stieleiche (Quercus robur L.) in einem Auenwald. PhD thesis, University of Freiburg, Germany.

Basra, A.S., and R.K. Basra. 1997. Mechanisms of Environmental Stress Resistance in Plants. Harwood Academic Publishers, London, U.K.

Bertani, A., and R. Reggiani. 1991. Anaerobic metabolism in rice roots, pp. 187-200. In Plant Life Under Oxygen Deprivation. Jackson, M.B., Davies, D.D., and Lambers, H. (Eds.). Academic Publishing, The Hague, The Netherlands. 
Percival and Keary: Influence of Nitrogen Fertilization on Waterlogging Stresses

Chiatante, D., A. Di Iorio, L. Maiuro, and S.G. Scippa. 2000. Effect of water stress on root meristems in woody and herbaceous plants during the first stage of development, pp. 245-258. In The Supporting Roots of Trees and Woody Plants: Form Function and Physiology. Stokes, A. (Ed.). Kluwer Academic Publishers, Utrecht, The Netherlands.

Clark, A.J., W. Landolt, J. Bucher, and R.J. Strasser. 1998. The response of Fagus sylvatica to elevated $\mathrm{CO}_{2}$ and ozone probed by the JIP-test based on the chlorophyll fluorescence rise: OJIP, pp. 283-286. In Responses of Plant Metabolism to Air Pollution and Global Change. De Kok, J.L., and Stulen, I. (Eds.). Brackhuys Publishers, Leiden, The Netherlands.

- 2000. Beech (Fagus sylvatica L.) response to ozone exposure assessed with a chlorophyll a fluorescence performance index. Environmental Pollution (Barking, Essex: 1987) 109:501-507.

Crook, C.S. 1992. The feasibility of tree planting on landfill containment sites. Arboricultural Journal 16:229-241.

Dobson, M. 1995. Tree Root Systems. Arboriculture Research and Information Note. 130/95/ARB.

Drew, M.C., E.J. Sisworo, and L.R. Saker. 1979. Alleviation of waterlogging damage to young barley plants by application of nitrate and a synthetic cytokinin, and comparison between the effects of waterlogging, nitrogen deficiency and root excision. The New Phytologist $82: 315-329$.

Ellenberg, H. 1986. Vegetation Mitteleuropas Mit Den Alpen. Verlag Eugen Ulmer, Stuttgart, Germany.

Farrar, P.J., R.O. Slatyer, and J.A. Vrajil. 1989. Photosynthetic temperature acclimation in Eucalyptus species from diverse habitats and a comparison with Nerium oleander. Australian Journal of Plant Physiology 16:198-217.

Farrell, R.C.C., D.T. Bell, K. Akilan, and J.K. Marshall. 1996. Morphological and physiological comparisons of clonal lines of Eucalyptus camaldulensis. II. Responses to waterlogging/salinity and alkalinity. Australian Journal of Plant Physiology 23:509-518.

Gardiner, E.S., and J.D. Hodges. 1996. Physiological, morphological and growth responses to rhizosphere hypoxia by seedlings of North American bottomland oaks. Annals of Science Forestry. 53: 303-316.

GeBler, A., J. Kreuzwieser, T. Dopatka, and H. Rennenberg. 2002. Diurnal course of ammonium net uptake by the roots of adult beech (Fagus sylvatica) and spruce (Picea abies) trees. Plant and Soil 240:23-32.

Gilbertson, P., A.D. Kendle, and A. Bradshaw. 1985. Root growth and the problem of trees in urban and industrial areas, pp. 59-66. In Advances in Practical Arboriculture. Patch, D. (Ed.). London HMSO, Bulletin Forestry Commission No 65, London, U.K.

Gorzelak, A. 2000. Effect of flooding on the flora-The example of the flooding of the Oder in 1997. Beitrage fur Forstwirtschaft und Landschaftsokologie. 34:8-11.

Gravatt, D.A., and C.J. Kirby. 1998. Patterns of photosynthesis and starch allocation in seedlings of four bottomland hardwood tree species subjected to flooding. Tree Physiology 18:411-417.

Hermes, D. 2001. Tree Responses to Abiotic and Biotic Stress. Tree Line. September Edition. 4 pp.

Hitchmough, J.D. 1994. Urban Landscape Management. Publ Inkata Press, Sydney, Australia. 8 pp.

Hodgson, A.S., and D.A. MacLeod. 1987. Effects of foliar applied nitrogen on cotton waterlogged in a cracking grey clay. Australian Journal of Agricultural Research 38:681-688.

Huang, B. 1997. Mechanisms of plant resistance to waterlogging, pp. 59-81. In Mechanisms of Environmental Stress Resistance in Plants. Basra, A.S., and Basra, R.K. (Eds.). Harwood Academic Publishers, London, U.K.

Huang, B., J.W. Johnson, D.S. NeSmith, and D.C. Bridges. 1994a. Growth, physiology and anatomical responses of two wheat genotypes to waterlogging and nutrient supply. Journal of Experimental Botany 45:193-202. 1994b. Root and shoot growth of wheat genotypes in response to hypoxia and subsequent resumption of aeration. Crop Science 34:1538-1544.

Isebrands, J.G., R. Ceulemans, and B. Wiard. 1988. Genetic variation in photosynthetic traits among Populus clones in relation to yield. Plant Physiology and Biochemistry 26:427-437.

Kendle, A.D., and R. Sherman. 2004. Amelioration of underperforming soils, pp. 47-62. In Plant User Handbook. A Guide to Effective Specifying. Hitchmough, J.D., and Fieldhouse, K. (Eds.). Blackwell Publishing, Oxford, U.K.

Kozlowski, T.T., P.J. Kramer, and S.G. Pallardy. 1991. The Physiological Ecology of Woody Plants. Academic Press, San Diego, CA.

Kreuzwieser, J., S. Furniss, and H. Rennenberg. 2002. Impact of waterlogging on the $\mathrm{N}$-metabolism of flood tolerant and non-tolerant tree species. Plant, Cell \& Environment 25:1039-1049.

Lawlor, D.W. 2001. Photosynthesis, 3rd edition. Scientific Publishers Limited, Oxford, U.K.

Levitt, J. 1980. Responses of Plants to Environmental Stress, Vol. I. Academic Press, New York, NY. 6 pp.

Lichtenthaler, H.K., and A.R. Wellburn. 1983. Determinations of total carotenoids and chlorophylls a and b of leaf extracts in different solvents. Biochemical Society Transmycological 11:591-593.

Mackie-Dawson, L.A., P. Millard, and M.F. Proe. 1998. The effect of nitrogen supply on root growth and development in sycamore and Sitka spruce trees. Nutrient Cycling in Agroecosystems. 16:59-65.

Majdi, H., and P. Kangas. 1997. Demography of fine roots in response to nutrient applications in a Norway spruce stand in southwestern Sweden. Ecoscience. 4:199-205.

Maldonado Rodriguez, R. 2002. www.geocities.com/ResearchTriangle/ Thinktank/8970/main1.html (accessed 2002).

Marschner, H. 1995. Mineral Nutrition of Higher Plants, 2nd edition. Academic Press, London, U.K.

Mclean, S. 1993. An investigation into the tolerance of seven species of street tree to soil deoxygenation. Bachelor of Horticultural Science thesis, VCAH Burnley, Melbourne, Australia.

Mendelssohn, I.A., and M.T. Postek. 1982. Elemental analysis of deposits on the roots of Spartina alterniflora Loisel. American Journal of Botany 69:29-32.

Naidoo, L., and S. Naidoo. 1992. Waterlogging responses of Sporobolus virginicus (L.) Kunth. Oecologia 90:445-450.

Ort, D.R., and J.S. Boyer. 1985. Plant productivity, photosynthesis, and environmental stress, pp. 279-311. In Changes in Gene Expression in Response to Environmental Stress. Atkinson, B.C., and Walden D.B. (Eds.). Academic Press, New York, NY.

Percival, G.C. 2004. Tree roots and buildings, pp. 113-127. In Plant User Handbook. A Guide to Effective Specifying. Hitchmough, J.D., and Fieldhouse, K. (Eds.). Blackwell Publishing, Oxford, U.K.

Percival, G.C., and G.A. Fraser. 2001. Measurement of the salinity and freezing tolerance of Crataegus genotypes using chlorophyll fluorescence. Journal of Arboriculture 27:233-245.

Percival, G.C., and J. Hitchmough. 1995. Tree establishment and performance in a cool growing season arboretum. Arboricultural Journal 19:357-371.

Pezeshki, S.R., P.H. Anderson, and R.D. Delaune. 2000. Effects of nursery pre-conditioning on Panicum hemitomon and Sagittaria lancifolia used for wetland restoration. Restoration Ecology 8: 57-64.

Pregitzer, K.S., D.L. Dickmann, R. Hendrick, and P.V. Nguyen. 1990. Whole-tree carbon and nitrogen portioning in young hybrid poplars. Tree Physiology 7:79-93.

Ricard, B., T. Vantoai, P. Chourey, and P. Saglio. 1998. Evidence for the critical role of sucrose synthase for anoxic tolerance of maize roots using a double mutant. Plant Physiology 116:1323-1331.

Strasser, B.J., and R.J. Strasser. 1995. Measuring fast fluorescence transients to address environmental questions: The JIP test, pp. 977-980. In Photosynthesis From Light to Biosphere. Mathis, P. (Ed.). Kluwer Academic Publishers, Dordrecht, The Netherlands. 
Talouizite, A., and M.J. Champigny. 1988. Response of wheat seedlings to short-term drought stress with particular respect to nitrogen nutrition. Plant, Cell \& Environment 11:149-155.

Tan, W., T.J. Blake, and T.J.B. Boyle. 1992. Drought tolerance in fasterand slower growing black spruce (Picea mariana) progenies: II. Osmotic adjustments and changes of soluble carbohydrates and amino acids under osmotic stress. Physiologia Plantarum 85:645-651.

Vartapetian, B.B., and M.B. Jackson. 1997. Plant adaptations to anaerobic stress. Annals of Botany 79:3-20.

Von Caemmerer, S., and G.D. Farquhar. 1981. Some relationships between the biochemistry of photosynthesis and the gas exchange of leaves. Planta 153:376-387.

\section{Glynn C. Percival (corresponding author) \\ Plant Physiologist/Technical Support Specialist \\ R.A. Bartlett Tree Research Laboratory \\ The University of Reading \\ 2 Early Gate \\ Whiteknights, Reading, RG6 6AU, U.K. \\ gpercival@bartlettuk.com}

\section{Ian P. Keary \\ Research Assistant \\ School of Biological Sciences \\ The University of Reading \\ Whiteknights, Reading, RG6 6AU, U.K.}

Résumé. Les objectifs de cette étude étaient de déterminer l'influence de la fertilisation azotée sur la tolérance de l'arbre face à des conditions prolongées de sol imprégné d'eau et aussi de vérifier l'effet de la fertilisation azotée quant à l'aide que cela peut apporter à l'arbre pour se rétablir de dommages causés par un milieu imprégné d'eau, et ce dans le cas du chênes anglais (sensibilité moyenne à un milieu imprégné d'eau) et du hêtre européen (sensibilité élevée à un milieu imprégné d'eau) comme espèces expérimentales. Le chêne anglais a fait ses preuves en tant qu'espèce plus tolérante en milieu imprégné d'eau que le hêtre européen. La vitalité de l'arbre - telle que mesurée par la fluorescence de la chlorophylle, le taux de photosynthèse, le contenu en chlorophylle foliaire, la conductance stomatale, la concentration foliaire et racinaire en protéines, et le contenu foliaire en azote - était de manière notable plus élevée chez les arbres ayant fait l'objet d'une fertilisation azotée ajoutée dans les solutions d'eau pour imprégner le sol comparativement à ceux dont le sol était uniquement imprégné d'eau, et ce durant une période de 18 jours. Les mesures d'absorption de la lumière, de capture de la lumière, de transport d'électrons et des flux de dissipation par section foliaire transversale de photosystème II faites après la période de 18 jours d'imprégnation du sol ont indiqué une influence bénéfique de la fertilisation azotée sur les processus photosynthétiques à la cessation de la période d'imprégnation du sol. L'ajout d'azote a induit une allocation accrue de ressource en faveur des racines par rapport aux pousses terminales chez les deux espèces. À la fin de la cessation de la période des 18 jours d'imprégnation du sol, et après une période de 10 jours de régénération qui suivait cette précédente période, la croissance (surface foliaire, pousse, racine, masse totale sèche de la plante) était constamment plus élevée chez les arbres dont le sol avait été imprégné d'eau avec une fertilisation azotée comparativement aux arbres dont il n'y avait eu que de l'eau. Dans une étude séparée, le taux de reprise des arbres - tel que mesuré par la fluorescence de la chlorophylle, les degrés de photosynthèse, le contenu en chlorophylle foliaire et la conductance stomatale -, sur une période de six semaines suivants celle des 18 jours d'imprégnation du sol, était de 30 à 50\% plus élevé chez les arbres ayant eu une fertilisation azotée comparativement à ceux sans fertilisation, et ce indépendamment de l'espèce. Dans tous les cas, les arbres non fer- tilisés avaient la plus faible capacité de reprise. De plus, la surface foliaire, la pousse, la racine et la masse totale de la plante étaient plus élevées pour les arbres fertilisés que ceux non fertilisés. Les résultats de cette recherche indiquent 1) qu'une application de fertilisants azotées améliore la tolérance des arbres sous des conditions prolongées de milieu imprégné d'eau et 2) que les applications d'azote après le stress d'une imprégnation d'eau s'avérerait être bénéfique pour améliorer le degré de reprise et la croissance des arbres. D'un point de vue pratique, une fertilisation azotée $\geq 14,5 \mathrm{~g}$ en azote par litre d'eau est suggérée à titre préliminaire, et ce en se basant sur les résultats préliminaires de cette étude.

Zusammenfassung. Das Ziel dieser Studie war, den Einfluss von Stickstoffdüngern auf die Baumtoleranz gegenüber staunassen Böden zu bestimmen und den Einfluss von Stickstoffdüngern bei der Regeneration von Bäumen, die unter Staunässe gelitten haben zu untersuchen. Dafür verwendeten wir getopfte Englische Eiche (mittlere Staunässe) und Europäische Buche (empfindlich gegen Staunässe) als Testart. Die Englische Eiche erwies sich als staunässe-toleranter als die Europ. Buche. Die Vitalität, gemessen in Chlorophyll Fluoreszenz, Photosyntheserate, Blattchlorophyllgehalt, Stomata-Leitfähigkeit, Blatt- und Wurzelproteinkonzentration und Blattstickstoffgehalt war deutlich höher als Stickstoffdünger zu den staunassen Bäumen zugefügt wurden gegenüber den Bäumen, die nur für 18 Tage mit Leitungswasser getränkt waren. Die Messung der Lichtabsorbierung, Lichtfang, Elektronentransport und Verlust pro Blattdurchmesser des Photosystems II nach den 18 Tagen Staunässe zeigten eine positiven Einfluss der Stickstoffdüngung auf den Photosyntheseprozess am Ende der Staunässeperiode. Die Zugabe von N führte bei beiden Baumarten. zu einer größeren Verteilung zugunsten der Wurzeln gegenüber den Trieben. Am Ende der 18 Tage Staunässe und 10 anschließenden Tagen der Regeneration war das Wachstum (Blattfläche, Triebe, Wurzel, totales Pflanzengewicht) in stickstoffgedüngten staunassen Bäumen, verglichen zu staunassen Bäumen ohne N. In einer separaten Studie waren die Daten der Bäume, gemessen als Chlorophyll Fluoreszenz, Photosyntheserate, Blattchlorophyllgehalt und Stomata-Leitfähigkeit nach einer 6wöchigen Periode nach der Beendigung der 18 Tage Staunässe in stickstoffgedüngten Bäumen um 30 - 50 \% höher als in ungedüngten Bäumen, unabhängig von der Baumart. In allen Fällen hatten die ungedüngten Bäume die geringste Fähigkeit zur Erholung. Auch die Blattfläche, Triebe, Wurzeln und totales Pflanzentrockengewicht waren bei gedüngten Bäumen größer als in ungedüngten. Die Ergebnisse dieser Untersuchung zeigen: 1) die Gabe von Stickstoffdüngern verbessert die Toleranz von Bäumen bei Staunässe und 2) die Gabe von Stickstoffdüngern nach dem Wasserstress kann den Bäumen helfen, sich zu erholen. Vom praktischen Standpunkt wird N-Düngung $\geq 14,5 \mathrm{~g}$ N/l vorläufig basierend auf den Ergebnissen dieser Studie empfohlen.

Resumen. Los objetivos de este estudio fueron determinar la influencia de los fertilizantes nitrogenados $(\mathrm{N})$ sobre la tolerancia del árbol bajo condiciones prolongadas de inundación e investigar el efecto de la fertilización con $\mathrm{N}$ como ayuda para la recuperación del daño usando encino inglés en contenedor (inundación intermedia) y la haya europea (inundación sensible), como especies de prueba. El encino inglés probó ser más tolerante a la inundación que la haya europea. La vitalidad del árbol medida por la fluorescencia de clorofila, tasas fotosintéticas, contenido de clorofila en la hoja, conductancia estomatal, concentración de proteína de la hoja y raíces y contenido de $\mathrm{N}$ foliar fueron consistentemente más altos en los árboles donde los fertilizantes con $\mathrm{N}$ fueron agregados a las soluciones de inundación, comparados a los árboles con inundación menor solamente por 18 días. La medición de la absorbancia lumínica, transporte de electrones y disipación de flujos por sección de área foliar del fotosistema II, luego del período de 18 días de inundación, indicó una influencia benéfica de la fertilización con $\mathrm{N}$ sobre los procesos fotosintéticos de la hoja en el período de cese de la inundación. La adición de $\mathrm{N}$ indujo mayor disposición de los recursos a favor de la raíces sobre los brotes, en ambas especies de árboles. Al momento del cese de la inundación del período de 18 días y los siguientes 10 días de 
recuperación, el crecimiento (área foliar, brotes, raíces, peso seco total de la planta) fueron constantemente más altos en los árboles con $\mathrm{N}$ comparados con los que no lo tuvieron. En un estudio separado, las tasas de recuperación de los árboles, medida por la fluorescencia de clorofila, tasas fotosintéticas, contenido de clorofila foliar y fluorescencia estomatal, sobre un período de seis semanas después del cese de la inundación, fueron 30 - 50\% más altos en los árboles fertilizados con $\mathrm{N}$, comparados con los no fertilizados, independientemente de las especies. En todos los casos los árboles no fertilizados tuvieron la más baja capacidad de recuperación. Además, el área foliar, brotes, raíces y peso seco total de la planta fueron más altos en los árboles fertilizados con $\mathrm{N}$ comparados con los no fertilizados. Los resultados de esta investigación indican i) las aplicaciones de fertilizantes con $\mathrm{N}$ refuerzan la tolerancia de los árboles bajo condiciones de inundación prolongada y ii) las aplicaciones de fertilizantes con $\mathrm{N}$ después del estrés de la inundación deberán beneficiar el mejoramiento de las tasas de recuperación de los árboles y el crecimiento. Desde un punto de vista práctico la fertilización con $\geq 14.5 \mathrm{~g}(0.52 \mathrm{oz}) \mathrm{N}$ por litro $(0.26 \mathrm{gal})$ de agua es una dosis tentativamente sugerida con base en los resultados preliminares de este estudio. 